\title{
ANALISIS SISTEM MANAJEMEN KESELAMATAN DAN KESEHATAN KERJA PADA PT. PLN (PERSERO) SEKTOR PEMBANGKIT TELLO KOTA MAKASSAR
}

\author{
${ }^{1)}$ A. Haslindah, ${ }^{2)}$ Jamaluddin, ${ }^{3)}$ Gita Saputri Kasman \\ ${ }^{1)}$ Dosen Program Studi Teknik Industri Fakultas Teknik Universitas Islam Makassar \\ ${ }^{2)}$ Dosen Program Studi Teknik Mesin Fakultas Teknik Universitas Islam Makassar \\ ${ }^{3)}$ Mahasiswi Program Studi Teknik Industri Fakultas Teknik Universitas Islam Makassar \\ Jl.Perintis Kemerdekaan KM 9 NO 29 Kampus UIM, Tlpn 0411-588-167 \\ Email :1) andihaslindah.dty.@uim-makassar.ac.id, ${ }^{21}$ jamaluddin.dty@uim-makassar.ac.id \\ ${ }^{3)}$ Ghetaputri07@gmail.com
}

\begin{abstract}
ABSTRAK
Penelitian ini dilakukan di PT PLN (Persero) Sektor Pembangkit Tello bertujuan untuk mengetahui bagaimana tingkat efektifitas SMK3 dan Bagaimana Kecelakaan Dan Penyakit Yang Terjadi Akibat Kerja pada PT. PLN (Persero) Sektor Pembangkit Tello. Metode penelitian kuantitatif, dimana proses awal dengan mengumpulkan data dari seluruh karyawan dengan teknik purposive sampling, kemudian dilakukan uji Validitas dan uji Realibilty berdasarkan hasil data yang didapatkan pada PT PLN (Persero) Sektor Pembangkit Tello. hasil uji data tersebut bahwa data yang diperoleh adalah valid dan relibel. selanjutnya dilakukan rekapitulasi persentase pelaksanaan SMK3 dari data yang didapatkan nilai persentase keseluruhan adalah 94\%. Dengan nilai persentase tersebut maka kriteria tingkat pelaksanaan SMK3 PT PLN (Persero) Sektor Pembangkit Tello berada pada kriteria memuaskan. Hal ini pada mengacu pada Tingkat penilaian keberhasilan SMK3 menurut PERMEN 05 tahun 1996 yang telah disesuaian dengan PP No. 50/2012 merupakan indikator keberhasilan penerapan SMK3 oleh suatu perusahaan.
\end{abstract}

\section{Kata Kunci: K3, Sistem Manajemen Keselamatan Dan kesehatan (SMK3).}

\section{PENDAHULUAN}

\subsection{Latar Belakang}

Untuk Menjalankan perusahaan secara produktif dan efisien sangat tergantung pada manajemen perusahaan. Salah satu bidang yang harus dikelola dengan baik adalah keselamatan dan kesehatan kerja (K3). PT. PLN Sektor Pembangkit Tello Makassar adalah salah satu pembangkit PT. PLN (Persero) yang hadir untuk memenuhi kebutuhan listrik khusunya untuk wilayah Sulawesi Selatan, Tenggara dan Barat. Perusahaan yang bergerak dibidang listrik, PT. PLN (Persero) Sektor Pembangkit Tello, Harus memeberikan pelayanan yang maksimal. Dalam hal manajemen K3 pihak manajemen PT. PLN (Persero) Sektor Pembangkit Tello harus memberikan perhatian lebih karena dampak yang diperoleh dari maksimal kinerja K3 sangat baik untuk pihak manajemen kedepannya.

\subsection{Rumusan Masalah}

Dari uraian yang telah dikemukakan dalam latar belakang masalah maka dirumuskan permasalahan bagaimana tingkat Efektifitas Sistem Manajemen K3 ?

\subsection{Tujuan Penelitian}

Tujuan dari penelitian ini adalah :

1. Untuk mengetahui tingkat efektifitas sistem manajemen kesehatan dan keselamatan kerja

2. Untuk mengetahui kecelakaan dan penyakit yang terjadi akibat kerja.

\subsection{Manfaat Penelitian}

Sebagai acuan didalam melakukan pengendalian masalah sistem manajemen keselamatan kerja (SMK3) di dalam perusahaan khususnya di PT. PLN (Persero) Sektor Pembangkit Tello Makassar. 


\section{METODOLOGI PENELITIAN}

\subsection{Tempat dan Waktu}

Penelitian ini dilakukan pada PT. PLN (Persero) Sektor Pembangkit Tello. Penelitian ini dilakukan selama 1(satu) Bulan pada Kota Makassar.

\subsection{Metode Analisis}

1. Peneliti menggunakan uji validasi dan uji realibilty melalui pengolahan data program SPSS versi 16, untuk menguji keabsahan data yang digunakan.

2. Hasil dan pembahasan merupakan penelitian kuantitatif.

3. Peneliti menggunakan teknik purpose sampling.

\subsection{Definisi Operasional dan Kriteria Objektif}

1. Pelaksanaan Sistem Manajemen Keselamatan dan Kesehatan Kerja (SMK3) Meliputi kesehatan kerja, pengaman, alat angkut, alat angkat, tempat dan cara penyimpanan material, perencanaan darurat, penanggulangan kebakaran, P3K, laporan kecelakaan, Pemeriksaan kecelakaan, analisis kecelakaan, Alat Pelindung Diri, promosi keselamatan dan kesehatan kerja, lingkungan kerja dan kebersihan sesuai dengan pertanyaan dari kuesioner.

2. Kriteria tingkat penilaian Pelaksanaan SMK3

kriteria tingkat pencapaian SMK3 merupakan kebijakan dari Permenaker No 05/1996 dan berdasarkan sistem manajemen keselamatan dan kesehatan kerja sesuai PP No. 50/2012 :

a. Kurang : Bila tingkat pencapaian perusahaan menerapkan kriteria $0-59 \%$ dari seluruh kriteria yang ditanyakan.

b. Baik : Bila tingkat pencapaian perusahaan menerapkan kriteria $60-84 \%$ dari seluruh kriteria yang ditanyakan.

c. Memuaskan : Bila tingkat pencapaian perusahaan menerapkan kriteria $85-100 \%$ dari seluruh kriteria yang ditanyakan

\subsection{Teknik Pengumpulan Data}

Untuk memperoleh informasi data yang dibutuhkan dalam skripsi ini maka menggunakan metode melalui:
1. Metode Observasi: yaitu metode yang dilakukan dengan melihat secara langsung objek yang berhubungan dengan permasalahan yang dibahas.

2. Metode Kuisioner : kuisioner berupa angket merupakan teknik pengumpulan data yang dilakukan melalui pemberian pertanyaan-pertanyaan secara tertulis kepada responden untuk dijawab. Pertanyaan kuisioner pada penelitian ini bersifat tertutup.

3. Study Literatur : merupakan metode yang dilakukan dengan menggunakan beberapa buku yang berhubungan dengan masalah yang dibahas.

\section{ANALISA DAN PEMBAHASAN}

Berdasarkan hasil pengumpulan data yang didapatkan pada penelitian di PT PLN (Persero) Sektor Pembangkit Tello melalui penyebaran kuisioner dengan jumlah sampel lima puluh satu responden, dimana objek yang digunakan dalam penelitian ini adalah karyawan PT PLN (Persero) Sektor Pembangkit Tello yang disebar pada unit unit kerja yakni Sektor PLTU, dan PLTG , maka hasil data tesebut dilakukan pengujian data yaitu Uji Validitas Dan Uji Realibility

\subsection{Uji validitas pelaksanaan Sistem Manajemen keselamatan dan kesehatan kerja \\ Untuk mengetahui apakah data tersebut} valid atau reliable selanjutnya dilakukan uji validitas pada data kuisioner menggunakan rumus dibawah ini :

$$
\begin{array}{r}
\mathrm{r}=\frac{N\left(\sum x y\right)-\left(\sum x \sum y\right)}{\sqrt{\left[\left(N \sum x^{2}\right)-\left(\sum x\right)^{2}\left(N \sum Y^{2}\right)-\left(\sum y\right)^{2}\right]}} \\
\mathrm{r}_{\text {hitung }}=\frac{51(3859)-(50.3936)}{\sqrt{\left[51(50)-(50)^{2}\right]\left[51(305496)-(3936)^{2}\right]}} \\
=\frac{196.809-196.800}{\sqrt{[2550-2500][29.596 .096-15.492 .096]}} \\
r_{\text {hitung }}=\frac{9}{\sqrt{[50][88200]}}=4,28
\end{array}
$$

Hasil $r$ hitung $>$ dari $r$ table $(4,28>0,232$ ) maka data dinyatakan valid. Selain menghitung dengan rumus, Dalam penelitian ini uji validitas dilakukan ,Uji validitas dalam penelitian ini menggunakan bantuan SPSS versi 16. Selanjutnya koefisien korelasi yang diperoleh $r_{\text {hitung }}$ masih harus diuji signifikan 
dengan membandingkannya dengan $r_{\text {tabel }}$, untuk degree of freedom $(\mathrm{df})=\mathrm{n}-2$ dalam hal ini (n) adalah jumlah sampel $(\mathrm{n})=51$ dan besarnya df dapat dihitung $\mathrm{df}=51-2=49$, dan alpha $(\alpha)=0,05$ di dapat $r_{\text {tabel }}=0.232$. Bila $r_{\text {hitung }}>$ dari $r_{\text {tabel }}$, maka nomor pertanyaan tersebut dinyatakan valid. Untuk perhitungan selanjutnya menggunakan softwere SPSS versi 16.

\subsection{Uji Keandalan pada Pelaksanaan SMK3.}

Perhitungan dilakukan dengan bantuan softwere SPSS versi 16. Data dikatakan reliabel apabila nilai chronbach alpha $>0,6$ atau $\alpha>0,6$. Hasil pengolahan tersebut dapat dilihat pada tabel dibawah ini.

\section{Tabel 1. Hasil Uji Reliability Kuesioner} pelaksanaan SMK3

\begin{tabular}{|r|r|}
\multicolumn{2}{|c|}{ Reliability Statistics } \\
\hline $\begin{array}{c}\text { Cronbach's } \\
\text { Alpha }\end{array}$ & $\begin{array}{c}\text { N of } \\
\text { Items }\end{array}$ \\
\hline, 933 & 80 \\
\hline
\end{tabular}

Dari output dapat diketahui nilai relibiabilitas instrumen pada nilai Cronbach's Alpha sebesar 0.933. karena nilai lebih dari $0.6(0,933>0,6)$ maka dapat disimpulkan bahwa instrumen pada variabel tersebut adalah reliabel.

\subsection{Tingkat Efektifitas pelaksanaan SMK3.}

Serta tingkat efektifitas pada pelaksanaan SMK3 oleh PT PLN (persero) sektor tello pembangkit dapat diketahui melalui penilaian berdasarkan hasil data dari responden pada Rekapitulasi Persentase Pelaksanaan SMK3 pada PT PLN (Persero) Sektor Pembangkit Tello dapat diketahui tingkat efektitas pelaksanaan SMK3 berdasarkan kriteria sebagai berikut :

1. Berdasarkan hasil penelitian untuk tingkat pencapaian pelaksanaan smk3 yang berada pada range persentase: $0-59 \%$ dari total kriteria bahwa tidak terdapat jumlah persentase yang berdara pada range tersebut. Dan tidak dinyatakan kurang dalam pelaksanaan SMK3 PT PLN (Persero) Sektor Pembangkit Tello

2. Berdasarkan hasil penelitian untuk tingkat pencapaian pelaksanaan SMK3 yang berada pada range persentase: $60-84 \%$ dari total kriteria bahwa tidak terdapat jumlah persentase yang berdara pada range tersebut meskipun tingkat pencapaian pelaksaaan SMK3 PT PLN (Persero) Sektor Pembangkit Tello dengan kriteria yang dinyatakan baik.

3. Berdasarkan hasil penelitian untuk tingkat pencapaian pelaksanaan SMK3 yang berada pada range persentase: 85 - $100 \%$ dari total kriteria bahwa semua persentase berada pada kriteria pelaksanaan SMK3 dengan tingkat pelaksanaan SMK3 PT PLN (Persero) Sektor Pembangkit Tello adalah memuaskan.

\subsection{Hambatan Penerapan SMK3.}

Meskipun tingkat efektifitas pelaksanaan SMK3 berada pada kategori memuaskan berdasarkan kesesuaian standar kriteria oleh PP No. 50/2012 bahwa terdapat masalah dalam penerapannya diantaranya $4 \%$ yang belum terlaksana dari $96 \%$ atau sedikitnya 3 kriteria dari 80 item pertanyaan tersebut adalah:

1. Mengadakan perawatan khusus untuk alat pelindung diri (APD)

2. Pemeriksaan kualitas alat pelindung diri secara berkala

3. pemerikasaan Pintu-pintu jalaur evakuasi keselamatan para pekerja

\section{ANALISA DAN PEMBAHASAN}

Melalui hasil penelitian juga di peroleh beberapa solusi dari permasalahan diatas diantaranya 1. Dengan memperkerjakan karyawan sesuai dengan keahliannya masingmasing serta merealisasikan kebijakan K3 dengan kata-kata yang mudah di mengerti oleh karyawan dan melakukan inspeksi alat keselamatan kerja 2. Dengan memberikan pelatihan-pelatihan bagi karyawan mengenai prosedur kerja yang telah di tetapkan serta melakukan briefing-briefing kecil saat akan melakukan tugas atau saat melakukan pekerjaan, maka dapat dikatakan bahwa jika penerpan SMK3 dilakukan secara professional dan berkesinambungan, maka akan tercipta tempat kerja yang aman, efisien dan produktif sehingga dapat mengurangi dan mengendalikan resiko kerja yang dapat merugikan seluruh pihak.

Kendala lainnya yang dihadapi oleh perusahaan yaitu kecelakaan dan penyakit 
akibat kerja berdasarkan data yang diperoleh, penyakit kerja belum didokumentasikan oleh pihak PT. PLN (Persero) Sektor Pembangkit Tello.

\section{PENUTUP}

\subsection{Kesimpulan}

1. Sistem manajamen keselamatan dan kesehatan pada PT PLN (persero) Sektor pembangkit Tello kota makassar sudah memenuhi kriteria pelaksanaan SMK3 yang sesuai PP No 50/2012 dengan kriteria pelaksanaan SMK3 yang memuaskan. Dengan pelaksanaan yang sudah diterapakan sebanyak 77 kriteria dari 80 kriteria / item pertanyaan atau 96\%. Dan hanya sedikitnya 3 kriteria atau $4 \%$ saja yang belum diterapkan. Meskipun tingkat efektifitas SMK3 pada PT PLN (Persero) Sektor pembangkit Tello sudah memuaskan namun masih saja ada hambatan yang ditemukan diantaranya 1 . Mengadakan perawatan khusus untuk alat pelindung diri (APD), 2. Pemeriksaan kualitas alat pelindung diri secara berkala, 3. pintu - pintu jalur evakuasi keselamatan para pekerja. Dengan program K3 yang dilaksanakan tiap tahunnya akan dilakukan lagi pengkajian sebagai evaluasi yang merupakan fungsi SMK3 dengan memasukkan poin hambatan tersebut ke perencanaan program $\mathrm{K} 3$ tahunan, dengan melihat tujuan program k3 pada PT PLN (Persero) Sektor pembangkit tello adalah kecelakaan nihil (zero accident).

2. Kecelakaan dan penyakit yang terjadi pada PT PLN (Persero) Sektor Pembangkit Tello masih dialami pada karyawan. Meski demikian kecelakaan dan penyakit yang terjadi akibat kerja sudah terminalisir terbukti dengan tingkat efektifitas SMK3 yang sudah memuaskan dengan terus dilakukan pengendalian dengan penerapan tingkat disiplin kerja oleh bagi semua karyawan pada PT PLN (Persero) Sektor Pembangkit Tello Makassar.

\subsection{Saran}

1. Perusahaan di harapkan menstabilkan pelaksanaan Sistem manajemen Keselamatan dan Kesehatan Kerja (SMK3) agar kecelakaan dan penyakit akibat kerja tidak terjadi lagi.
2. Perusahan diharapan melakukan pemeriksaan berkala mengenai pemakaian APD untuk mencegah pemakaian APD yang tidak layak oleh tenaga kerja sehingga dapat terhindar dari kecelakaan dan penyakit akibat kerja.

\section{DAFTAR PUSTAKA}

Ahmad Hanafie, A.Haslindah, Muh. Fadhli (2015), Pengembangan Mesin Perontok Padi (Combine Harverter) yang Ergonomis Untuk Meningkatkan Produksi, Prosiding Seminar Nasional Tahunan Teknik Mesin Indonesia-XIV, Banjarmasing, 7-8 Oktober 2015.

Ahmad Hanafie, Andi Haslindah, Saripuddin M (2017), Karakteristik Antropometri Pengguna Mesin Perontok Padi (Combine Harverter) Pengelolaan Hasil Panen yang Ergonomis, Prosiding Seminar Nasional Telnologi Indonesia V, hal 52-57, Makassar 12 Juli 2017.

Ahmad Hanafie (2007), Modifikasi Helm Standar Kendaraan Roda Dua Yang Ergonomis Bagi Penguna Telpon Seluler, Jurnal Iltek, Vol. II, Nomor 4, April 2007, Hal 313-319, Fakultas Teknik Univ. Islam Makassar.

Duwi Priyatno. 2016. Belajar alat analisis data dan cara pengolahannya dengan SPSS. Gava Media. Yogyakarta

Dr. Badruddin, M.Ag. 2014. Dasar- dasar manajemen, Alfabeta. Bandung

Indah rachmatiah siti salami,dkk. 2015. Kesehatan dan keselamatan lingkungan kerja, Gadja Mada University press. Yogyakarta

Implementasi Permen Nomor: PER.05/MEN/1996. Tentang Sistem Manajemen Keselamatan Dan Kesehatan Kerja. Jakarta 2013.

J. M Harrington, F. S Gill . 2005. Buku kesehatan kerja, EGC: edisi 3. Jakarta

Kisme. 2004. Statistik dan laporan kecelakaan kerja.

Muhammad Rusli. Buku Pengolahan Statistik Yang menyenangkan, Graha Ilmu.

Prof, Drs. C.S.T. Kansil, S.H, Cristine S.T. Kansil, S.H., M.H. buku kitab Undangundang Ketenagakerjaan. Buku Edisi Kedua.Undang-undang No 25 Tahun 1997 
Dan Peraturan Pelaksanaan

ketenagakerjaan 1925-2000.

Soehatman Ramli. 2010. Sistem Manajemen

Keselamatan Dan Kesehatan Kerja, Seri

Manajemen K3 01. Dian Rakyat. Jakarta.

V. Wiratna Sujarweni. 2014. Metodologi

Penelitian. Pustaka Baru Press.

Yogyakarta.

http://www.a2k4-ina.net/informasi/163-

sistim-manajemen-keselamatan-dan-

kesehatan-kerja-smk3-sesuai-pp-no-50-

tahun-2012

http://dwipermana.blogs.uny.ac.id/2016/06/15

lartikel-kesehatan-dakeselamatan-kerja-k3-

ergonomi-dalam-kesehatan-dan-

keselamatan-kerja-k3/.

https://sistemmanajemenkeselamatankerja.blo gspot.co.id/2013/09/dasar-hukum-k3-

keselamatan-dan.html.

Suradi, H. Abbas, W. Tjaronge, V. Sampebulu, Estimation of Standard Time in Production of Light Weight Brick Manufacturing Using Ball Mill, International Journal of Advances in Scientific Research and Engineering (ijasre.net), ISSN 2454-8006 Volume-2, Issue-1,January-2016 